\title{
Polymeric nanoparticles - a novel solution for delivery of antimicrobial agents
}

\section{Nanocząstki polimerowe jako nowe nośniki leków przeciwdrobnoustrojowych}

\author{
Grzegorz Michalak¹, Katarzyna Głuszek², Ewelina Piktel', Piotr Deptuła', Irena Puszkarz³, \\ Katarzyna Niemirowicz ${ }^{1}$, Robert Bucki ${ }^{1,4}$ \\ 'Department of Microbiological and Nanobiomedical Engineering, Medical University of Bialystok, Bialystok, Poland \\ Head of the Department: Prof. Robert Bucki PhD \\ ${ }^{2}$ Holy Cross Oncology Center of Kielce, Kielce, Poland \\ Head of the Center: Stanisław Góźdź MD, PhD \\ ${ }^{3}$ Doctoral Studies, Faculty of Medical and Health Sciences, Jan Kochanowski University, Kielce, Poland \\ Head of the Faculty: Prof. Stanisław Głuszek MD, PhD \\ ${ }^{4}$ Department of Pathophysiology and Infection Microbiology, Institute of Medical Sciences, Faculty of Medicine and Health Sciences, \\ Jan Kochanowski University, Kielce, Poland \\ Head of the Department: Prof. Robert Bucki MD, PhD
}

Medical Studies/Studia Medyczne 2016; 32 (1): 56-62

Key words: antibiotics, infections, polymer nanoparticles, nanotechnology.

Słowa kluczowe: antybiotyki, infekcje, nanocząstki polimerowe, nanotechnologia.

\begin{abstract}
The increased prevalence of antibiotic-resistant pathogens requires additional efforts to develop new antimicrobial agents and alternative methods to prevent and treat infections. In response to this challenge, a variety of nanotechnology-based tools are currently being designed and thoroughly investigated. To date, a considerable number of studies have reported increased activity of antibiotic-conjugated polymeric nanoparticles against bacteria and fungi associated with various infections, including those caused by drug-resistant pathogens. Importantly, high biocompatibility of these structures coupled with enhanced biological activity and improved pharmacokinetic properties supports the potential of these nanosystems as new tools to treat infections. In this review, we summarize the synthesis of polymer-based nanoparticles and describe their mechanism of action. We also highlight the recent advances in the application of antibiotic-conjugated polymeric nanoparticles as novel antimicrobial agents.
\end{abstract}

\section{Streszczenie}

Stale narastająca lekooporność drobnoustrojów wymusza konieczność rozwoju alternatywnych metod profilaktyki i terapii zakażeń, a także uzasadnia prace nad nowymi lekami o aktywności przeciwdrobnoustrojowej. Realizacja tego celu jest możliwa dzięki zastosowaniu osiągnięć z zakresu nanotechnologii. Zwiększająca się liczba doniesień literaturowych potwierdza znaczną aktywność przeciwdrobnoustrojową nanocząstek polimerowych skoniugowanych z klasycznymi antybiotykami, co może zostać wykorzystane w terapii infekcji o charakterze bakteryjnym i grzybiczym, również tych wywoływanych przez patogeny lekooporne. Wysoka biokompatybilność nanocząstek polimerowych, a także możliwość zwiększania aktywności przeciwdrobnoustrojowej i poprawy parametrów farmakokinetycznych stosowanych obecnie chemioterapeutyków, wskazuje na możliwość zastosowania nanostruktur w nowoczesnej terapii chorób infekcyjnych. W niniejszej pracy podsumowano metody syntezy nanosystemów opartych na nanocząstkach polimerowych, a także opisano mechanizm ich działania. Przedstawione zostały również najnowsze osiągnięcia w syntezie nanocząstek skoniugowanych z antybiotykami, pozwalające na ich zastosowanie w terapii infekcji o charakterze bakteryjnym i grzybiczym.

\section{Introduction}

Over the past decades a reduction in the introduction of novel antibiotics coupled with the expansion of drug-resistant pathogens has become an ever-increasing problem in the public health service. The rapid development of nanotechnology provides new safe and effective antimicrobial therapies and constitutes a favorable approach in the modern treatment of bacterial and fungal infections, particularly those caused by antibiotic-resistant pathogens. To date, a number of novel antibiotic analogs and nanomate- 
rials including magnetic nanoparticles, lipid-based and polymeric nanoparticles have been investigated as new treatments against pathogens in planktonic and biofilm form [1-5]. Their use as drug nanocarriers is further supported by the strong antimicrobial activity of the nanostructures [6]. Importantly, the introduction of nanotechnology in the treatment of bacterial and fungal infections presents a number of advantages over conventional antimicrobial therapy. Specifically, nanosystems offer antibiotic delivery to the site of infection and extension of its action due to controlled release [7]. Additionally, the use of nanotechnology provides important improvements in the pharmacokinetics of antibiotics whose application is limited due to low solubility, poor bioavailability after oral administration, short half-life, high toxicity or instability in physiological conditions (Figure 1) [8-10]. A broad spectrum of antimicrobial activity described for a variety of nanomaterials supports the idea that the employment of antibiotic-conjugated nanoformulations will provide a more efficient way to overcome the ever-growing drug resistance of pathogens $[11,12]$.

In this review we briefly summarize the potential of nanomaterials to improve the antimicrobial activity of conventional antibiotics and highlight the recent advances in the application of antibiotics functionalized with nanoscale materials as novel drug nanocarriers.

\section{Synthesis of polymeric nanoparticles}

Polymeric nanoparticles (PNPs), including nanocapsules and nanospheres, are prepared from different kinds of polymers that range in size from 10 to $1000 \mathrm{~nm}$ [13]. Polymers used in nanoparticle preparation should be biocompatible with the host cells, specifically non-toxic and non-antigenic [14]. Moreover, PNPs should be biodegradable in the human body. Biodegradation plays a key role in the nanocarrier pharmacokinetic profile via sustained release properties, sub-cellular size and biocompatibility with various cells and tissues [15]. The most common materials used in the preparation of PNPs can be divided into natural and synthetic polymers [13]. Natural polymers include polysaccharides (chitosan, cellulose, guar gum, dextran, hyaluronic acid, etc.) and family proteins or polypeptides (albumin, gelatin, elastin, gliadin, legumin, etc.) [16, 17]. The principal advantage of natural polymers is the presence of hydrophilic groups such as carboxyl, hydroxyl and amino groups, which controls their solubility in water and allows the formation of non-covalent bonds (hydrogen and/or electrostatic bonds) with biological tissues and mucosal membranes [18]. Additionally, this property provides the opportunity for chemical modification of the macromolecule surface to immobilize drugs, homing ligands and other active agents $[16,19]$.
Synthetic polymers are the second category of materials appealing for the design of polymeric nanoparticles and include polylactides (PLA), polyglycolides (PGA), poly(ethylene glycol) (PEG), polycaprolactone (PCL), poly(acrylic acid) derivatives (PAA) and copolymers such as poly(lactide co-glycolides) (PLGA), poly(e-caprolactone)-Pluronic, and poly(ethylene glycol)-poly(2-methyl-2-carboxyl-propylene carbonate) (MPEG-PMBC), etc. [20-22].

There are different methods of fabrication to acquire the desired PNP properties. The preparation method depends on the type of polymeric matrix, size distributions, future application, etc. Two techniques of polymerization are generally employed: preformed polymers or ionic gelation. Methods for preparation of nanoparticles from dispersion of preformed polymers include nanoprecipitation, solvent evaporation emulsification/solvent diffusion, salting out, supercritical fluid (SCF) technology and dialysis. These methods are commonly used to prepare drug to be loaded into biodegradable nanoparticles from polylactides (PLA), polyglycolides (PGA) and those copolymers. Preparation of nanoparticles from polymerization of monomers can be accomplished by different methods such as emulsion preparation, mini- and macro-emulsion, interfacial polymerization and controlled/living radical polymerization, e.g. RAFT [13]. In addition, polymeric nanoparticles may also be used as a reaction or dispersion medium for the synthesis of nanoparticles [23]. Regardless of the synthesis method used, PNPs that are prepared for biomedical applications should be completely free from unreacted reagents, organic solvents, surfactants or traces of heavy metals or catalysts $[24,25]$. Recent studies show that the pharmacokinetic parameters of the drug are greatly influenced by the selected drug's molecular weight, polymeric composition (type, hydrophobicity, biodegradation and controlled release profile) of nanoparticles, localization of drug in the nanospheres, and drug incorporation techniques such as adsorption or incorporation [26-29].

Drug immobilization on the polymeric nanoparticles can be performed in several ways. One approach is based on incorporation into the internal part of nanoparticles, which may be achieved via encapsulation or imprinting of active molecules during or after the fabrication process. A second technique consists of drug immobilization on the surface of polymeric nanocarriers through the engagement of covalent or non-covalent bonds [30,31]. The polymeric nanocarriers release the drug at the site of action by one of three general physicochemical mechanisms: (i) via swelling of the polymer nanoparticles by hydration, (ii) by an enzymatic reaction resulting in the cleavage of bonds and degradation of the polymer at the site of delivery and (iii) by de-adsorption of drugs from the swelled nanoparticles [32-34] (Figure 1). 


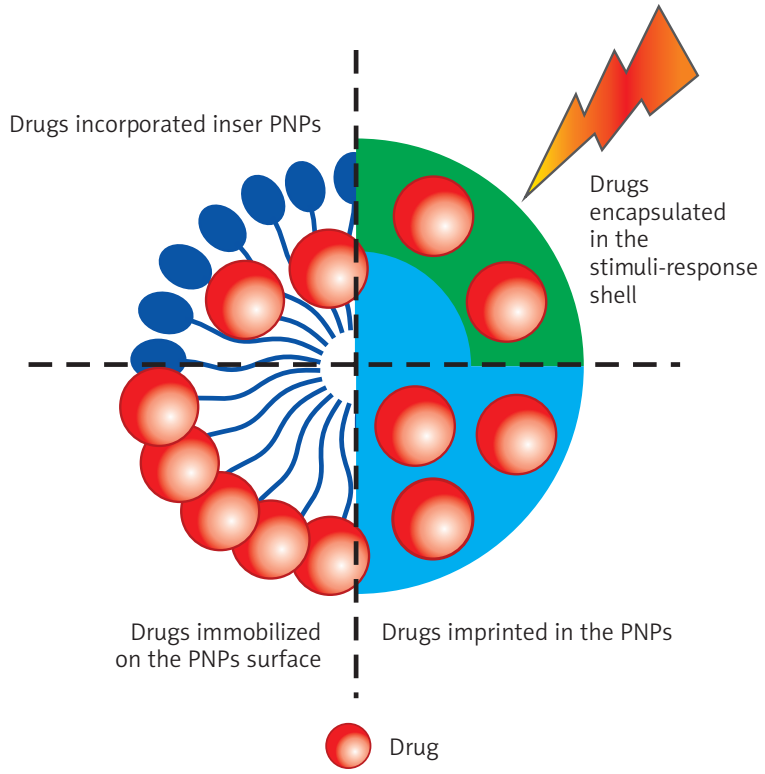

Figure 1. Strategies of drug immobilization on polymeric nanoparticles

\section{Mechanism of action}

Polymeric nanoparticles possess unique properties for antimicrobial drug delivery. Firstly, PNPs may be composed of different types of monomers, which provide the opportunity to manipulate PNP stability and allow for control of their biodegradation profile. Secondly, particle properties such as size, thickness of layers, zeta potentials, and presence of active groups can be precisely tuned by selecting the appropriate technique such as controlled polymerization, for example reversible addition-fragmentation chain transfer (RAFT) [35].

Polymeric nanoparticles may interact with the bacterial cell wall via passive or active targeting (Figure 2). Passive targeting is based on particle size and the ability of PNPs to form pores, which disrupt the structure of the pathogen membrane [23, 36, 37]. Recent studies indicate that conjugation of lectin-specific ligands on the PNP surface showed enhanced binding affinity to the carbohydrate receptors on the Helicobacter pylori membrane [38]. In another study Jain et al. used concanavalin-A (Con-A) decorated elastin as a clarithromycin delivery system for $H$. $p y$ lori eradication [39]. In active targeting other homing molecules including specific antibodies and aptamer bacteriophage proteins have been used for nanoparticle surface functionalization resulting in targeted delivery platforms effective against different types of bacterial infections [37, 40, 41]. Targeting molecules can also be used for sensitive and specific identification strategies for detection of pathogens such as Staphylococcus aureus, Mycobacterium tuberculosis and Escherichia coli via aptamer recognition and fluorescently tagged silica nanoparticles [42-44]. Increasing evidence suggests that encapsulation of antimicrobial agents on PNPs enhances their activity [7, 45, 46]. In

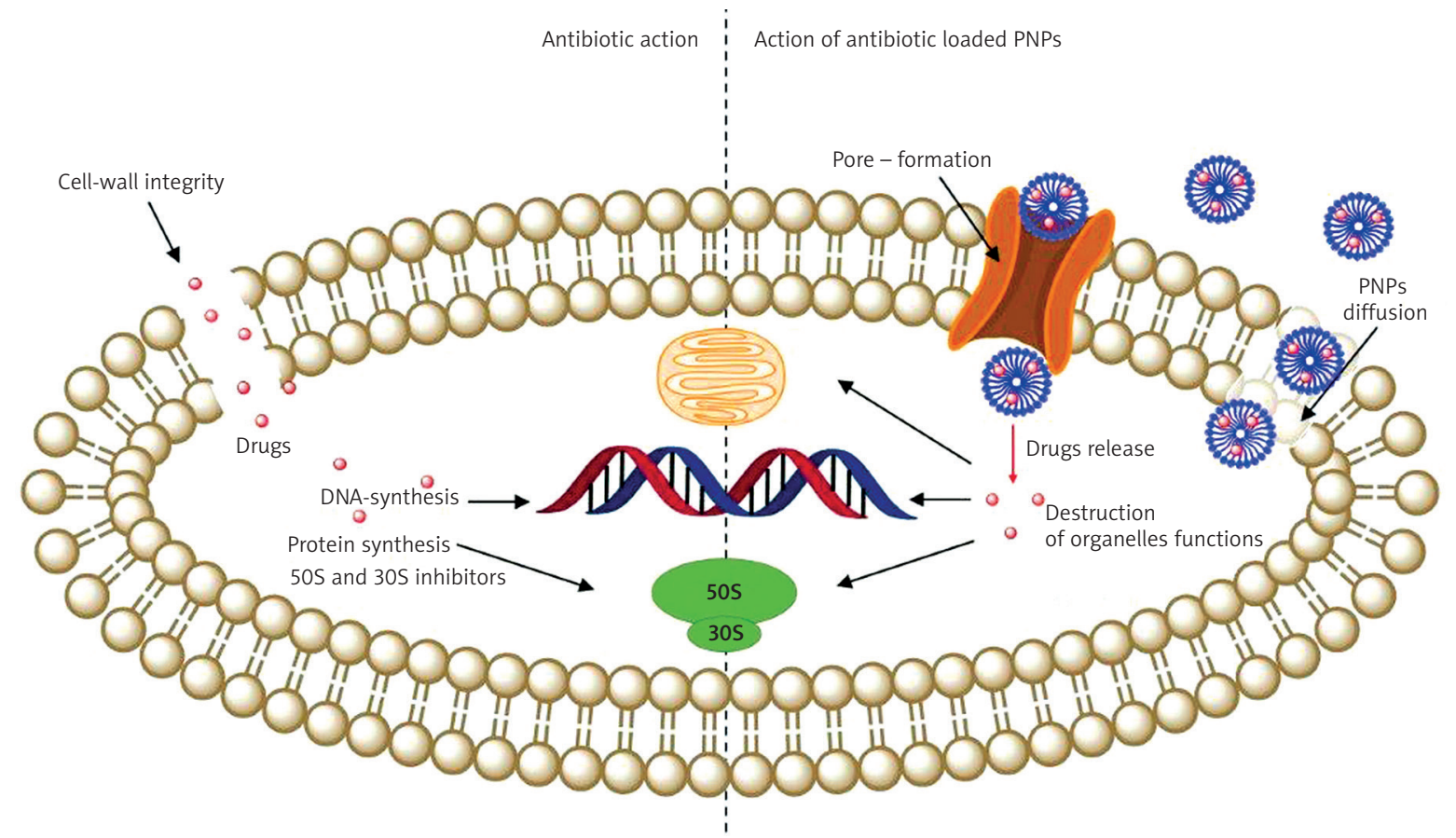

Figure 2. Schematic representation of antibiotic action in free form compared to antibiotic loaded on polymeric nanoparticles 
addition, recent data show that polymeric nanoparticles have the ability to penetrate biofilms [47] and that polymeric nanoparticles are able to improve the delivery of antibiotics to the bacterial cells embedded in biofilm matrix, thereby increasing the efficacy of the treatment [48].

\section{Recent advances in application of antibiotic- conjugated nanoparticles in treatment of infections}

The rapid development of nanotechnology results in the production of numerous nanosystems shown to be effective antimicrobial agents for the treatment of bacterial and fungal infections. The design of PNPs containing conventional antibiotics as the therapeutic agents supported by the antimicrobial properties of nanosystems alone offers the potential to overcome limitations facing conventional antibiotic therapy. Jamil et al. demonstrated that cefazolin-loaded chitosan nanoparticles can be employed as stable and effective agents against multidrug-resistant Klebsiella pneumoniae, Pseudomonas aeruginosa and extended spectrum beta lactamase (ESBL) positive E. coli [11] Novel studies performed by Cai et al. revealed that the treatment of $H$. pylori with amoxicillin and pectin sulfate-loaded lipid PNPs significantly eradicates H. pylori in the biofilm form, inhibits bacteria from adhering to gastric cells and decreases the MIC value for amoxicillin, which increases its ability to inhibit bacterial colonization despite the well-known resistance of H. pylori to antimicrobial treatment [12]. Additionally, Hussein-Al-Ali et al. reported strong antimicrobial potential of streptomycin-conjugated magnetic nanoparticles coated with chitosan against drug-sensitive $S$. aureus and its methicillin-resistant counterpart (MRSA), which might be a promising strategy to fight drug-resistant infections, particularity those reported in the hospital environment [46]. Recently, chitosancoated alginate (CS-ALG) nanoparticles were proposed for a facilitated ocular delivery system of daptomycin for the treatment of MRSA-originated endophthalmitis [49].

A number of studies have also established that nanotechnology-based achievements can be employed to improve the pharmacokinetic properties and affect the pharmacological properties of commonly used antibiotics and commercially available formulations. Recent studies have focused in part on the improvement of amphotericin B biocompatibility using nanotechnology-based tools. Its employment is limited due to poor biodistribution, low solubility and high nephrotoxicity leading to kidney failure. In order to bypass these obstacles Italia et al. entrapped amphotericin B into PLGA nanoparticles, which resulted in improvement or oral bioavailability and reduced nephrotoxicity [50]. Similar results from Tang et al. [51] indicate increased fungicidal activity of amphotericin B after incorporation into polymeric nanoparticles. It was also shown that encapsulation of amphotericin B poly(L-lactide) (PLA) nanoparticles reduces hemolytic activity of the drug without affecting its antifungal properties [10]. Moreover, a study from 2013 reported that amphotericin B-encapsulated PLGA-DMSA (poly[lactic-co-glycolic] acid and dimercaptosuccinic acid) nanoparticles might be an effective delivery system for the treatment of cutaneous leishmaniasis [52]. Nanoparticle-related approaches designed to control release of gentamicin may also have clinical usefulness. It is well known that gentamicin, due to its broad spectrum of activity, is an important antimicrobial agent used widely for treatment of $P$. aeruginosa infections. However, its short half-life, low bioavailability and severe oto- and nephrotoxicity caused by gentamicin significantly hamper its use in common antibiotic therapies [53]. In order to overcome these restrictions, Abdelghany et al. demonstrated that the entrapment of gentamicin in PLGA nanoparticles controlled the release of gentamicin and subsequently enhanced its antimicrobial activity against the planktonic and biofilm forms of $P$. aeruginosa without inducing side effects observed earlier during the course of therapy [7]. Moreover, incorporation of a third-generation cephalosporin, ceftriaxone sodium, into chitosan-based nanoparticles allows for cellular penetration of the antibiotic, in contrast to the free non-modified drug, whose application in the treatment of intracellular pathogens (e.g. Salmonella) is limited due to the high molecular weight and hydrophobicity of ceftriaxone [54]. Enhancement of solubility followed by increased antibiotic activity is also possible due to the design of antibiotic-conjugated polyacrylate nanoparticles effective in the killing of drug-resistant pathogens, including MRSA [55].

Apart from the reports indicating the improved safety of nanoparticle-based formulations when compared to their non-modified counterparts, Ong et al. demonstrated a novel prodrug of meropenem formulated into mucus-penetrating crystals as a tool for administration of drugs via inhalation. A number of studies performed by this research team confirmed the maintenance of meropenem levels in guinea pig lungs after treatment with meropenem-loaded nanoformulation without the undesirable effects of inhalation therapy, observed as the effect of lung accumulation of drugs and conventional polymeric nanocarriers, particularly in chronic use [56]. Furthermore, it is postulated that PLGA-incorporated aminoglycosides possess the potential to be employed in aerosol delivery for the treatment of pulmonary infections due to the controlled release of antibiotic from the nanocarrier [7].

The use of polymeric nanomaterials also allows for the design of drug forms previously inapplicable due to low antibiotic solubility. An example is the drug ciprofloxacin, commonly administered orally and intravenously. Studies performed by Parwe et al. in- 
dicated that the synthesis of ciprofloxacin conjugated with biodegradable PLA allows for the introduction of ciprofloxacin for topical use based on a biocompatible nanofiber mat used as wound dressing material (bandage) [57]. The application of PLGA-based nanoparticles is also the starting point for the synthesis of an injectable nanoparticle-loaded system for the local delivery of antibiotics during bone infections. The treatment of bone infections is hampered due to the required use of high antibiotic doses (which is associated with numerous side effects), lack of site specificity and invasiveness of the implanting form of drugs. These limitations might be overcome through the design of platforms for controlled delivery of vancomycin in osteomyelitis treatment, as proposed recently by Posadowska et al. A broad spectrum of advantages are offered by this nanoformulation, including biocompatibility, self-healing ability after disruption, easy application and controlled drug release followed by strong activity against $S$. aureus [58]. Recently, the same research team presented a similar formulation, based on gentamycin incorporated within the gellan gum hydrogel and into PLGA nanoparticles embedded into the hydrogel for the localized treatment of bone infections [59].

\section{Conclusions and perspectives for the future}

It is possible that the rapid development of nanotechnology-based tools designed for the treatment of infections will lead in the near future to the development of innovative strategies and therapeutic options for patients suffering from bacterial and fungal infections. Considering the emerging problem of microbial multidrug resistance with subsequently a decreasing number of novel antibiotics introduced for clinical use, the design of antibiotic-conjugated nanostructures may provide a feasible and desirable approach in the therapy of infections. Additionally, the advantages obtained from functionalization of antimicrobial agents supported by antimicrobial properties of nanoscale materials may overcome the limitations facing modern antibiotic therapy. Given the above, we might also expect that a growing interest in nanotechnology-based antimicrobial therapies will result in the design of novel formulations such as core-shell nanostructure including metal-based nanoparticles functionalized by antiseptic agents or other molecules with an antimicrobial mode of action.

\section{Conflict of interest}

The authors declare no conflict of interest.

\section{References}

1. Esmaeili A, Ghobadianpour S. Vancomycin loaded superparamagnetic $\mathrm{MnFe}_{2} \mathrm{O}_{4}$ nanoparticles coated with PEGylated chitosan to enhance antibacterial activity. Int J Pharm 2016; 501: 326-30.
2. Gannimani R, Ramesh M, Mtambo S, Pillay K, Soliman ME, Govender P. gamma-Cyclodextrin capped silver nanoparticles for molecular recognition and enhancement of antibacterial activity of chloramphenicol. J Inorg Biochem 2016; 157: 15-24.

3. Cui H, Li W, Li C, Vittayapadung S, Lin L. Liposome containing cinnamon oil with antibacterial activity against methicillin-resistant Staphylococcus aureus biofilm. Biofouling 2016; 32: 215-25.

4. Wnorowska U, Watek M, Durnaś B, Głuszek K, Piktel E, Niemirowicz K, Bucki R. Extracellular DNA as an essential component and therapeutic target of microbial biofilm. Studia Medyczne 2015; 31: 132-8.

5. Surel U, Niemirowicz K, Marzec M, Savage PB, Bucki R. Ceragenins - a new weapon to fight multidrug resistant bacterial infections. Studia Medyczne 2014; 30: 207-13.

6. Singh R, Smitha MS, Singh SP. The role of nanotechnology in combating multi-drug resistant bacteria. J Nanosci Nanotechnol 2014; 14: 4745-56.

7. Abdelghany SM, Quinn DJ, Ingram RJ, Gilmore BF, Donnelly RF, Taggart CC, Scott CJ. Gentamicin-loaded nanoparticles show improved antimicrobial effects towards Pseudomonas aeruginosa infection. Int J Nanomed 2012; 7 : 4053-63.

8. Patel PA, Patravale VB. AmbiOnp: solid lipid nanoparticles of amphotericin B for oral administration. J Biomed Nanotechnol 2011; 7: 632-9.

9. Chaudhari MB, Desai PP, Patel PA, Patravale VB. Solid lipid nanoparticles of amphotericin B (AmbiOnp): in vitro and in vivo assessment towards safe and effective oral treatment module. Drug Deliv Transl Res 2015 Dec 28 [Epub ahead of print].

10. Casa DM, Carraro TC, de Camargo LE, Dalmolin LF, Khalil NM, Mainardes RM. Poly(L-lactide) nanoparticles reduce amphotericin B cytotoxicity and maintain its in vitro antifungal activity. J Nanosci Nanotechnol 2015; 15: 848-54.

11. Jamil B, Habib H, Abbasi S, Nasir H, Rahman A, Rehman A, Bokhari H, Imran M. Cefazolin loaded chitosan nanoparticles to cure multi drug resistant Gram-negative pathogens. Carbohydr Polym 2016; 136: 682-91.

12. Cai J, Huang H, Song W, Hu H, Chen J, Zhang L, Li P, $\mathrm{Wu}$ R, Wu C. Preparation and evaluation of lipid polymer nanoparticles for eradicating $\mathrm{H}$. pylori biofilm and impairing antibacterial resistance in vitro. Int J Pharm 2015; 495: 728-37.

13. Prasad Rao JG, Kurt E. Polymer nanoparticles: preparation techniques and size-control parameters. Progress in Polymer Science 2011; 36: 887-913.

14. Lerch S, Dass M, Musyanovych A, Landfester K, Mailänder V. Polymeric nanoparticles of different sizes overcome the cell membrane barrier. Eur J Pharm Biopharm 2013; 84: 265-74.

15. Mahapatro A, Singh DK. Biodegradable nanoparticles are excellent vehicle for site directed in-vivo delivery of drugs and vaccines. J Nanobiotechnol 2011; 9: 55.

16. Swierczewska M, Han HS, Kim K, Park JH, Lee S. Polysaccharide-based nanoparticles for theranostic nanomedicine. Adv Drug Deliv Rev 2015 Nov 27. pii: S0169409X(15)00279-3. doi: 10.1016/j.addr.2015.11.015. [Epub ahead of print].

17. Peng $\mathrm{Q}, \mathrm{Mu} \mathrm{H}$. The potential of protein-nanomaterial interaction for advanced drug delivery. J Control Release 2016; 225: 121-32. 
18. Singh D, Han SS, Shin EJ. Polysaccharides as nanocarriers for therapeutic applications. J Biomed Nanotechnol 2014; 10: 2149-72.

19. Herrera Estrada LP, Champion JA. Protein nanoparticles for therapeutic protein delivery. Biomater Sci 2015; 3: 787-99.

20. Lee JI, Yoo HS. Biodegradable microspheres containing poly(epsilon-caprolactone)-Pluronic block copolymers for temperature-responsive release of proteins. Colloids Surf B Biointerfaces 2008; 61: 81-7.

21. Kumar N, Ravikumar MN, Domb AJ. Biodegradable block copolymers. Adv Drug Deliv Rev 2001; 53: 23-44.

22. Luo YY, Xiong XY, Tian Y, Li ZL, Gong YC, Li YP. A review of biodegradable polymeric systems for oral insulin delivery. Drug Deliv 2015 Jun 24: 1-10. [Epub ahead of print].

23. Palza H. Antimicrobial polymers with metal nanoparticles. Int J Mol Sci 2015; 16: 2099-116.

24. Moritz M, Geszke-Moritz M. Recent developments in the application of polymeric nanoparticles as drug carriers. Adv Clin Exp Med 2015; 24: 749-58.

25. Vauthier C, Bouchemal K. Methods for the preparation and manufacture of polymeric nanoparticles. Pharm Res 2009; 26: 1025-58.

26. Ambruosi A, Khalansky AS, Yamamoto H, Gelperina SE, Begley DJ, Kreuter J. Biodistribution of polysorbate 80-coated doxorubicin-loaded [14C]-poly(butyl cyanoacrylate) nanoparticles after intravenous administration to glioblastoma-bearing rats. J Drug Target 2006; 14: 97-105.

27. Al Zaki A, Hui JZ, Higbee E, Tsourkas A. Biodistribution, clearance, and toxicology of polymeric micelles loaded with 0.9 or $5 \mathrm{~nm}$ gold nanoparticles. J Biomed Nanotechnol 2015; 11: 1836-46.

28. Chawla R, Solanki HS, Kheruka SC, Gambhir S, Dube V, Aggarwal LM, Mishra B. Polylactide-co-glycolide nanoparticles of antitubercular drugs: formulation, characterization and biodistribution studies. Ther Deliv 2014; 5: 1247-59.

29. Yu H, Tang Z, Zhang D, Song W, Zhang Y, Yang Y Pharmacokinetics, biodistribution and in vivo efficacy of cisplatin loaded poly(L-glutamic acid)-g-methoxy poly(ethylene glycol) complex nanoparticles for tumor therapy. J Control Release 2015; 205: 89-97.

30. Akagi T, Kaneko T, Kida T, Akashi M. Multifunctional conjugation of proteins on/into bio-nanoparticles prepared by amphiphilic poly(gamma-glutamic acid). J Biomater Sci Polym Ed 2006; 17: 875-92.

31. Grabnar PA, Kristl J. The manufacturing techniques of drug-loaded polymeric nanoparticles from preformed polymers. J Microencapsul 2011; 28: 323-35.

32. Pang X, Jiang Y, Xiao Q, Leung AW, Hua H, Xu C. pH-responsive polymer-drug conjugates: design and progress. J Control Release 2016; 222: 116-29.

33. Khan H, Shukla RN, Bajpai AK. Genipin-modified gelatin nanocarriers as swelling controlled drug delivery system for in vitro release of cytarabine. Mater Sci Eng C Mater Biol Appl 2016; 61: 457-65.

34. Boer GJ, Kruisbrink J. A polymeric controlled drug delivery device for peptides based on a surface desorption/diffusion mechanism. Biomaterials 1987; 8: 265-74.

35. Wilczewska A, Markiewicz K. Surface-initiated RAFT/ MADIX polymerization on Xanthate-coated iron oxide nanoparticles. Macromolecular Chemistry and Physics 2014; 215: 190-7.
36. Danhier F, Ansorena E, Silva JM, Coco R, Le Breton A, Préat V. PLGA-based nanoparticles: an overview of biomedical applications. J Control Release 2012; 161: 505-22.

37. Gao W, Thamphiwatana S, Angsantikul P, Zhang L. Nanoparticle approaches against bacterial infections. Wiley Interdiscip Rev Nanomed Nanobiotechnol 2014; 6: 532-47.

38. Umamaheshwari RB, Jain NK. Receptor mediated targeting of lectin conjugated gliadin nanoparticles in the treatment of Helicobacter pylori. J Drug Target 2003; 11: 415-23; discussion 23-4.

39. Jain SK, Jangdey MS. Lectin conjugated gastroretentive multiparticulate delivery system of clarithromycin for the effective treatment of Helicobacter pylori. Mol Pharm 2009; 6: 295-304.

40. Satishkumar R, Vertegel AA. Antibody-directed targeting of lysostaphin adsorbed onto polylactide nanoparticles increases its antimicrobial activity against $\mathrm{S}$. aureus in vitro. Nanotechnology 2011; 22: 505103.

41. Tay LL, Huang PJ, Tanha J, Ryan S, Wu X, Hulse J, Chau LK. Silica encapsulated SERS nanoprobe conjugated to the bacteriophage tailspike protein for targeted detection of Salmonella. Chem Commun (Camb) 2012; 48: 1024-6.

42. He X, Li Y, He D, Wang K, Shangguan J, Shi H. Aptamerfluorescent silica nanoparticles bioconjugates based dualcolor flow cytometry for specific detection of Staphylococcus aureus. J Biomed Nanotechnol 2014; 10: 1359-68.

43. Qin D, He X, Wang K, Tan W. Using fluorescent nanoparticles and SYBR Green I based two-color flow cytometry to determine Mycobacterium tuberculosis avoiding false positives. Biosens Bioelectron 2008; 24: 626-31.

44. He X, Zhou L, He D, Wang K, Cao J. Rapid and ultrasensitive E. coli O157:H7 quantitation by combination of ligan dmagnetic nanoparticles enrichment with fluorescent nanoparticles based two-color flow cytometry. Analyst 2011; 136: 4183-91.

45. Barreras US, Méndez FT, Martínez RE, Valencia CS, Rodríguez PR, Rodríguez JP. Chitosan nanoparticles enhance the antibacterial activity of chlorhexidine in collagen membranes used for periapical guided tissue regeneration. Mater Sci Eng C Mater Biol Appl 2016; 58: 1182-7.

46. Hussein-Al-Ali SH, El Zowalaty ME, Hussein MZ, Ismail M, Webster TJ. Synthesis, characterization, controlled release, and antibacterial studies of a novel streptomycin chitosan magnetic nanoantibiotic. Int J Nanomed 2014; 9: 549-57.

47. Cheow WS, Hadinoto K. Antibiotic polymeric nanoparticles for biofilm-associated infection therapy. Methods Mol Biol 2014; 1147: 227-38.

48. Forier K, Raemdonck K, De Smedt SC, Demeester J, Coenye $\mathrm{T}$, Braeckmans $\mathrm{K}$. Lipid and polymer nanoparticles for drug delivery to bacterial biofilms. J Control Release 2014; 190: 607-23

49. Costa JR, Silva NC, Sarmento B, Pintado M. Potential chitosan-coated alginate nanoparticles for ocular delivery of daptomycin. Eur J Clin Microbiol Infect Dis 2015; 34: 1255-62.

50. Italia JL, Yahya MM, Singh D, Ravi Kumar MN. Biodegradable nanoparticles improve oral bioavailability of amphotericin B and show reduced nephrotoxicity compared to intravenous Fungizone. Pharm Res 2009; 26: 1324-31. 
51. Tang X, Zhu H, Sun L, Hou W, Cai S, Zhang R, Liu F. Enhanced antifungal effects of amphotericin B-TPGSb-(PCL-ran-PGA) nanoparticles in vitro and in vivo. Int J Nanomed 2014; 9: 5403-13.

52. de Carvalho RF, Ribeiro IF, Miranda-Vilela AL, de Souza Filho J, Martins OP, Cintra e Silva DeO, Tedesco AC, Lacava $Z G$, Bao SN, Sampaio RN. Leishmanicidal activity of amphotericin B encapsulated in PLGA-DMSA nanoparticles to treat cutaneous leishmaniasis in C57BL/6 mice. Exp Parasitol 2013; 135: 217-22.

53. Tange RA, Dreschler WA, Prins JM, Büller HR, Kuijper EJ, Speelman P. Ototoxicity and nephrotoxicity of gentamicin vs netilmicin in patients with serious infections. A randomized clinical trial. Clin Otolaryngol Allied Sci 1995; 20: 118-23.

54. Zaki NM, Hafez MM. Enhanced antibacterial effect of ceftriaxone sodium-loaded chitosan nanoparticles against intracellular Salmonella typhimurium. AAPS Pharm Sci Tech 2012; 13: 411-21.

55. Turos E, Shim JY, Wang Y, Greenhalgh K, Reddy GS, Dickey S, Lim DV. Antibiotic-conjugated polyacrylate nanoparticles: new opportunities for development of anti-MRSA agents. Bioorg Med Chem Lett 2007; 17: 53-6.

56. Ong W, Nowak P, Cu Y, Schopf L, Bourassa J, Enlow E, Moskowitz SM, Chen H. Sustained pulmonary delivery of a water-soluble antibiotic without encapsulating carriers. Pharm Res 2016; 33: 563-72.

57. Parwe SP, Chaudhari PN, Mohite KK, Selukar BS, Nande SS, Garnaik B. Synthesis of ciprofloxacin-conjugated poly (L-lactic acid) polymer for nanofiber fabrication and antibacterial evaluation. Int J Nanomed 2014; 9: 1463-77.

58. Posadowska U, Brzychczy-Wloch M, Pamula E. Injectable gellan gum-based nanoparticles-loaded system for the local delivery of vancomycin in osteomyelitis treatment. J Mater Sci Mater Med 2016; 27: 9.

59. Posadowska U, Brzychczy-Włoch M, Drożdż A, KrokBorkowicz M, Włodarczyk-Biegun M, Dobrzyński P, Chrzanowski W, Pamuła E. Injectable hybrid delivery system composed of gellan gum, nanoparticles and gentamicin for the localized treatment of bone infections. Expert Opin Drug Deliv 2016 Feb 16: 1-8 [Epub ahead of print].

\section{Address for correspondence:}

Prof. Robert Bucki PhD

Department of Microbiological

and Nanobiomedical Engineering

Medical University of Bialystok

ul. Mickiewicza 2 C, 15-222 Bialystok, Poland

Phone: +48 857485483

E-mail: mikro.nano@umb.edu.pl 